Article

\title{
Linguistic Meaning, Rigid Designators, and Legal Philosophy
}

\author{
Matthew McManus \\ Politics and International Relations, Tec de Monterrey, C.P 52926 Atizapan, Mexico; \\ mattmcmanus300@gmail.com
}

Received: 9 February 2019; Accepted: 26 March 2019; Published: 3 April 2019

\begin{abstract}
This essay is intended to engage some of the controversies that have emerged in legal philosophy concerning the theory of linguistic meaning we should adopt with reference to the law. In particular, I will focus on two theories of linguistic meaning that have opposing positions both on the nature of meaning, and the consequences this might have for law and legal objectivity. The first can be called plain meaning view. The plain meaning theory claims that the meaning of legal terms is a settled thing, and it is the duty of legal officials, especially judges, to simply apply that meaning to a given case in hand. In modern American jurisprudence, the plain meaning theory is often associated with various originalist figures, most notably the late Antonin Scalia who called his iteration of the plain meaning theory "textualism." For this reason, I will largely be focusing on Justice Scalia's account. The second theory of linguistic meaning I will be examining can be called the indeterminate theory. The indeterminate theory holds that there is no set or foundational meaning to any semantic term in the law which can be objectively applied by legal practitioners.
\end{abstract}

Keywords: law; legal philosophy; language

\section{Introduction}

As was pointed out by Peter Goodrich some time ago, legal philosophers rely on a fair amount of linguistic theory and the philosophy of language [1] (p. 63). This essay is intended to engage some of the controversies that have emerged in legal philosophy concerning the theory of linguistic meaning we should adopt with reference to the law. In particular, I will focus on two theories of linguistic meaning that have opposing positions both on the nature of meaning, and the consequences this might have for law and legal objectivity. The first can be called plain meaning view. The plain meaning theory claims that the meaning of legal terms is a settled thing, and it is the duty of legal officials, especially judges, to simply apply that meaning to a given case in hand. In modern American jurisprudence, the plain meaning theory is often associated with various originalist figures, most notably the late Antonin Scalia who called his iteration of the plain meaning theory "textualism." For this reason, I will largely be focusing on Justice Scalia's account. The second theory of linguistic meaning I will be examining can be called the indeterminate theory. The indeterminate theory holds that there is no set or foundational meaning to any semantic term in the law which can be objectively applied by legal practitioners. To understand what determines the outcome of legal cases one must not look at the semantic meaning of a legal term, rather one must look at the knowledge/power structures which contextualize a case. In modern American jurisprudence, the indeterminate theory is often associated with critical legal and post-modern figures, most notably Duncan Kennedy, Mariana Valverde, and Goodrich himself [1-3].

I will argue that both of these theories of meaning are mistaken for different reasons. On the first end, I will argue that the plain meaning theory is too simplistic in its assumptions and claims about linguistic meaning, both in itself and with regard to the possibility of legal objectivity. This is 
because the reasoning of the plain meaning theory, if pushed to its logical conclusion, would lead not to the positivistic ${ }^{1}$ conclusions its adherents hope for. Instead, it would lead to a kind of semantic holism which would be antithetical to the ambitions of those who hold to the plain meaning theory. I will conclude by arguing that many who hold to the plain meaning theory do so not because it is a particularly plausible theory of linguistic meaning, but because they are so ideologically committed to a (particular) understanding of legal objectivity that seems to require it. Thus, their commitment to the plain meaning theory is a blatant case of making assumptions about a descriptive state of affairs because one has certain normative preferences. This is especially true of originalists in American jurisprudence who still hold to the plain meaning theory. ${ }^{2}$

On the second end, I will suggest that the indeterminate theory of linguistic meaning falls victim to a similar mistake, albeit at a subtler level. The indeterminate theory of language is right to take the lesson, emphasized early on by Wittgenstein and picked up by many others, that social context contributes a great deal to the semantic meaning of various terms [4]. I also believe that those who hold to the indeterminate theory of linguistic meaning and give it a post-modern twist are correct to look at the ways forms of knowledge/power influence the way that law is both understood theoretically and deployed. However, I think that those who hold to the indeterminate theory of language put the case too strongly. This is because they place too much emphasis on semantic ambiguities that are actually often resolvable, and cash that out as a theory of legal indeterminancy. This is reflected in the excessive emphasis placed on "hard cases" and controversial legal issues ${ }^{3}$ that do not permit of one easy decision of another on the part of legal officials [5]. This distracts from the fact, which I will discuss at greater length in the conclusion, that many decisions in law are not hard in part because there is an unambiguous link between the semantic meaning of legal terms and the situation they are to be applied to.

In the conclusion, I will defend a preliminary account of linguistic meaning that I will call soft pragmatism and describe some consequences for legal analysis. My soft pragmatism draws primarily on the work of Kripke, Putnam, and Wittgenstein, though there is also an emphasis on the more radical work of Chomsky [6-9]. I will argue, following Kripke and Putnam, that just as there are rigid designators in regular language, so too there are legal terms which rigidly designate the situations they are to be unambiguously applied to [6,7]. Examples can include many cases where we apply reverse onus reasoning, such as giving speed tickets, or constitutional stipulations concerning the age one needs to be in order to assume the Presidency of the United States. In these instances, there is no indeterminancy about the law's meaning and application. However, I will also maintain that there are many situations where legal terms do not rigidly designate. This includes many examples in constitutional law, where there is far more ambiguity in how a legal term is to be deployed. In these instances, I will argue there is no determinate way to interpret the law's meaning and application. In these instances, judges engage in acts of "self-reflection" to develop a new meaning for a term within the established set of semantic associations that constitute precedents. These are not entirely

1 I refer to positivistic in both the linguistic and legal sense of the word. While there is a familial proximity that engenders connections between the two on the part of legal philosophers, there is no necessary conceptual connection between linguistic positivism and legal positivism. The previous century's most famous legal positivist, H.L.A Hart, seemed to eschew any kind of linguistic positivism. Indeed, in some respects Hart's rejection of linguistic positivism seems to have engendered certain insights on his part into the nature of legal positivism., for instance, how judges deal with "penumbral problems" in the law.

2 This is not true of all of them. More sophisticated variants of originalism have emerged which avoid this problem.

3 This can be extended beyond semantic issues to those concerning topics like "legal pluralism." Legal pluralism is an invaluable field that has done much to shake up rigid formalism in our understanding of the legal system. However, I think the case is sometimes put too strongly that traditional legal analysis does not have the means of developing a pluralistic understanding of law-like authority. For instance, there is nothing I see in Hart that precludes the possibility of competing or overlapping systems of authority. In fact, his descriptive sociology seems to presuppose that such systems will exist prior to the development of legality and persist after it. 
novel since they are still constrained by considerations of fit and pragmatic association with precedent. However, they are novel enough to constitute innovations in our understanding and application of law.

\section{The Plain Meaning Theory}

The plain meaning theory has a long and complex history in American jurisprudence, but throughout the basic orientation has remained consistent. It is that the semantic meaning of words in a language, and legal terms in particular, is more or less a matter of little controversy within a linguistic community at the time when they are written or uttered. The last point is important. Advocates of the plain meaning theory are under no illusions that the particular semantic associations proximate to a given term might change within a given linguistic community. However, they do not view this as important from a legal standpoint. Indeed, the fact that given semantic associations proximate to a given term might change is often seen as begetting an unfortunate temptation on the part of judges and legal officials. This temptation is for judges or other legal officials to adopt the modern plain meaning of a term when interpreting the law, rather than adopting the plain meaning it would have had when a given set of legal terms was arranged by lawmakers. ${ }^{4}$ Many advocates of the plain meaning theory view this updating as fundamentally wrong since it involves judicial officials updating the meaning of a legal term to denote something that was not intended by the original lawmakers. When combined with a certain account of democracy, this is viewed as usurping the right of a democratically elected government to bind the political community to a certain set of laws unless future lawmakers decide to change it. If they do not decide to do so, then one can implicitly assume the demos accepts and wishes to preserve the original plain meaning of the law, since it has not opted to change it. By doing so and updating the law to accord with the new plain meaning (as they understand it), judges and legal officials are usurping the rights of a democratically elected government.

There is no space here to discuss the association of the plain meaning theory with various theories of democracy and its discourses. However, I hope the account given above might explain why the plain meaning theory of legal language has come to be associated-in popular discourse, at least-with what has broadly been termed originalism. Some might take issue with this conflation, since it is singularly difficult to pin down an uncontroversial theory of linguistic meaning that would be acceptable to all originalists who have taken up the cause. One of the reasons I characterized this theory as the "plain meaning theory" is because I think it is a broad enough label to capture the essential features of what many classical originalist academics - and plenty of modern jurists in positions of power-have to say about language. Indeed, I would venture that without some theory of plain meaning, where the historical uncontroversial plain meaning of legal terms as it was when they were written or uttered can be discovered and reapplied by interpretation, many classical originalist doctrines would be without a leg to stand on.

Given that, I am hoping that most will accept my claim that most originalists held to some iteration of the plain meaning theory of language. Here I will nuance the story slightly. There generally there have been two distinctive iterations of the plain meaning theory. ${ }^{5}$ The first was the intentionalist

4 Even worse is simply inventing a new meaning.

5 Some originalists have adopted a midway position between intentionalism and its subjectivism and textualism and its apparent objectivity-the original understanding positions. This entails looking at what the original recipients of a legal text thought it meant. I admit to finding this position mysterious. It attempts to avoid the subjectivism of intentionalism by looking at the public statements of officials made after a legal document was ratified in the expectation that this will give the plain meaning of the text. But this strikes me as being neither fish nor fowl, and, therefore, unhelpful. It suggests that recipients transmitted the plain meaning of the text because they were proximate to its foundation. But there seems to be no good empirical reason to suppose that these individuals agreed on what the meaning of the legal terms was. The original understanding approach assumes arbitrary consistency and, as I shall point out, interpretive authority, on the part of recipients. Even if the recipients did share a common understanding of a set of legal terms, there seems to be little reason why their specific opinion should count for much. Unlike the intentionalist presumption, the recipients of a legal text cannot be said to have willed the law into being. They were not its specific authors. This is one of the reasons I believe the textualist account of the plain meaning view has gained more currency. By entirely eschewing subjectivism it at least evades most of the difficulties of needing to know the given mental state and interpretive pragmatics deployed by individuals who lived centuries ago. 
approach to legal meaning: that the law plainly means what its original drafters intended ${ }^{6}$ it to mean and that it is a judge's duty to interpret that as literally as possible. Important intentionalists include Michael J. Perry, and the late Judge Robert Bork who was perhaps the most famous and influential ${ }^{7}$ advocate of this theory $[10,11]$. The intentionalist approach, while once popular, has largely been abandoned for a variety of reasons. The most prominent is the sheer difficulty in determining with any certainty what any individual drafter, let alone a collection of them, intended when they drafted, say, a constitutional provision. ${ }^{8}$ And indeed, this difficulty seems largely unsolvable within the confines of what was ultimately an extremely primitive understanding of linguistic meaning. The most obvious reasons are that it attempts to develop a subjectivist account of meaning that flows from the author's intention, while ignoring the fact that, since there is no such thing as a private language (and certainly not one that would be useful for law), the meaning of a given set of terms if inherently constituted by inter-subjective activities. What is more, even if it were possible to develop a subjectivist account of meaning that related to an author's private intentions, it is not clear how any other lawmaker would, therefore, know what his peers intended by drafting a given law. Since each subject would intend for a legal term to have a given meaning known in its entirety only to themselves, there would be no way for an outsider to assume there was some consensus on what was intended by all the lawmakers when assembling a given set of legal terms.

For this, and other reasons, intentionalism has largely been superseded in the popular imagination by the textualist approach of Judge Antonin Scalia and others. For these reasons, I will focus largely on both unpacking and later criticizing the textualist iteration of the plain meaning theory rather than running through the rather anachronistic reasons why intentionalism does not hold together. The best example of the textualist iteration of the plain meaning theory is found in the work of Antonin Scalia, arguably the most famous Judge on the American Supreme Court within living memory. ${ }^{9}$

While his numerous juridical decisions and famously barbed dissents constitute the living example of Justice Scalia's textualist approach, Scalia's reasoning is made most explicit in his admirably concise and articulate essay "Common Law Courts in the Civil Law System" presented, alongside rebuttals and commentary, in A Matter of Interpretation: Federal Courts and the Law. Justice Scalia observed that there is a notable gap in American legal scholarship, namely, a settled account of how judges are supposed to go about interpreting the law. This is both unfortunate and dangerous given the important role that judges play in contemporary liberal democracies as interpreters of the common law. Notably, Justice Scalia claims to be in favor of judicial review as a "desirable limitation upon popular democracy." [12] (p. 12) However, he is deeply concerned about the attitude judges take when engaged in this essential task. Most particularly, Justice Scalia takes issue with those judges who believe it is their responsibility to develop an "evolving common law" in line with a more general approach which understands the Constitution to be "living." [12] (p. 12) To Justice Scalia's mind, this testifies to the need to resolve such controversies and develop a genuine "science" of judicial (specifically statutory) interpretation, if such a thing is possible [12] (p. 12).

6 Historically, intentionalism was also referred to as conventionalism. Because I find this term more ambiguous, I have opted to refer to intentionalism throughout this section.

7 Ronald Dworkin criticized intentionalism as a species of what he more broadly deemed conventionalism. The belief that rules about both legal institutions and the meaning of particular legal terms is settled by the agreement of lawmakers. Much of what Dworkin says is of interest, but I will not take it up here. It is unclear to me that he ever successfully updated his criticisms of conventionalism to fully counter challenge posed by the textualist iteration of the plain meaning theory, although I think he was devastatingly effective in criticizing its moral and political presumptions. See Ronald Dworkin. Law's Empire. (Cambridge, MA. Belknap Press, 1988).

8 Perhaps the most influential and powerful critiques on this point were made by Dworkin.

9 Justice Thomas is also an important figure in the shift away from intentionalism to a more ambiguous form of the plain meaning view that is largely textualist, but cherry picks from historical sources where necessary to reach a more "accurate" interpretation of legal terms. As he does not spell out his own judicial philosophy with the candour of Scalia, one must instead infer his approach from judgments and secondary readings. 
He then goes on to make a series of friendly, but critical observations about intentionalism. To avoid the invariably subjectivist tendencies that might flow from such an interpretive practice, these scholars looked less at what a specific legislator might have intended and more at the meaning which a subject is authorized to understand based on the specific semantic connotations of the law [12] (p. 17). But Justice Scalia rejects this approach as still overly subjectivist. When one asks not what a legislature meant but what they intended to say, too much confusion arises which provides judges with leeway to ascribe their own interpretations to the law in question [12] (p. 12). For instance, in the (in)famous Holy Trinity decision of 1892 the Court, unable to proceed using express materials, looked at the "unexpressed" legislative intent of the legislature to create a new class of individuals exempt from a statute prohibiting aliens from entering the United States to perform labor [12] (pp, 21).

By contrast, Justice Scalia argues that judges should look at what the words of a law objectively meant at the time it was passed. This can be done by looking at texts of the time, history, and of course, dictionaries. The possibility of making such a judgment depends on Justice Scalia's beliefs about semantic determinacy. He concedes that there may be room for differing interpretations about what the objective meaning of a word might be, but that there are clear limitations to such indeterminacy. In a key passage, Justice Scalia maintains that:

... While the good textualist is not a literalist, neither is he a nihilist. Words do have a limited range of meaning, and no interpretation beyond that range is permissible ... To state otherwise is to abandon textualism, and to render democratically adopted texts mere springboards for judicial lawmaking. [12] (pp. 21-22)

Scalia then provides a helpful example of what this theory of legal meaning entails in practice. Scalia refers to the case of Smith $v$. United States, where the defendant offered an unloaded firearm to a drug dealer in return for cocaine. Mr. Smith was liable to an enhanced penalty for using a firearm while committing a drug trafficking offence. Justice Scalia objected to this, because in his opinion a "proper textualist" would understand that using a gun involves using it as a weapon. He points out that when being asked "Do you use a cane?" one is "not inquiring whether (one) has hung his grandfather's antique can as a decoration in the hallway." [12] (p. 22)

Unfortunately, when giving an account of the textualist iteration of the plain meaning theory, there is not much else to go on besides this comment and Scalia's assertions that words have a limited range of meaning beyond which no other interpretation is possible. In much of the remaining essay, he proceeds to criticize constructivists, who maintain that there is a set of logical rules which allow good legal reasoners to literally "construct" the proper meaning of a law by relying on canons and presumptions, such as legislative debates which illustrate the intent of lawmakers. Justice Scalia regards this as a waste of time since many judges will find evidence that will pull them in different interpretive directions [12] (p. 33). Instead, one should determine the objective meaning of words by looking at the contexts, both historical and semantic, which indicates how the words were used at the time the law was passed. In this way, judges can (usually) arrive at an unobjectionable answer that conforms to the plain meaning legal terms had before they were written.

\subsection{The Limitations of the Plain Meaning Theory and Its Textualist Iteration}

This ends my summary of Justice Scalia's textualist iteration of the plain meaning theory. In this next section, I will be focusing on criticizing it.

The plain meaning theory has a superficial attraction to it. The most obvious is that it seems both common sensical from a theoretical point of view, but I suspect the deeper reason it is held to by advocates like Scalia is that the plain meaning theory meshes well with their more specifically moral convictions about the nature of law, and its relationship to democracy and legal officials. Indeed, Scalia and his admirers often put the cart before the horse on this point of contention. They are prone to maintaining, vigorously and at times dogmatically, that if language does not have a plain meaning, then it would make the "rule of law" impossible [12] (p. 24). Perhaps, though I am skeptical of such a 
radical either/or. But this is entirely besides the point. One cannot invoke a moral thesis about the necessity of law to justify a theory of semantic meaning. If it happens to be the case that there is no such thing as clear original meaning, then so much the worse for our considered moral judgments. In such a situation, we might simply be forced to reconsider what is meant by the rule of law rather than clinging to it through adhering to an untenable theoretical position. As nicely put by Leo Strauss:

"A wish is not a fact. Even by proving that a certain view is indispensable for living well, one proves merely that the view in question is a salutary myth: one does not prove it to be true. Utility and truth are two entirely different things." [13] (p. 6)

So, at least here, it strikes me as irrelevant whether the plain meaning theory is necessary for the preservation of the rule of law. Even if it were, that would not count for anything concerning the salience or not of the plain meaning theory as an account of language, even with regard to legal terms. What matters is the coherence and applicability of the theory on its own terms to the subject of semantic meaning, how it generates and is understood by members of a linguistic community. So, let us look at the tenability of the plain meaning theory in its textualist iteration. Recall that I focus on it here because I believe that the textualist iteration is the most powerful of the plain meaning theories. ${ }^{10}$

\subsection{Meaning Holism and Challenges to the Plain Meaning Theory}

As indicated, textualism argues that words have a limited range of plain meanings as determined both by the context in which they were written, and the use they were put to. To put it in a more technical way, the syntactic structure of assembled terms in a given statement takes on a semantic dimension through engagement with a community ${ }^{11}$ of language users. Over time, as these become calcified, the plain meaning of the terms in a given statement becomes determinate. This might seem relatively uncontroversial. The difficulties emerge when we try to look more concretely at what gives meaning to individual statements. Take as a very simple example the statement: "I am going to use a gun to rob a bank." What makes this sentence meaningful, and how can we be sure another ordinary language user would understand what its plain meaning is? As we shall see, I think it is very difficult to say an ordinary language user can unambiguously say what the plain meaning is in all cases. This poses a deep challenge to the plain meaning theory at a theoretical level. If true, it is even more problematic for a legal approach like textualism which is dependent on the plain meaning theory, since many of the terms deployed by legal officials are more ambiguous than those deployed by average members of a linguistic community. ${ }^{12}$

So, are plain meaning theories, and the textualist iteration presented, troubled by these ambiguities? I believe that they are. This is because the contextualism of the plain meaning theory pushes those who hold to it towards what I, following Putnam, call "meaning holism." [7] Meaning holism has been described many times. But it is essentially the idea that semantic meaning depends on what Wittgenstein called "the enormous system" of interrelated semantic associations that make up our linguistically coded knowledge of even the simplest things [14] (p. 52). The term "gun" for example, is simply a collection of symbols on a page or phonetic speech sounds, without these associations. The associations that make up my understanding of the word gun are vast and complicated. I can understand it as a weapon, or as a sporting tool, metaphorically as in "gunning" for a position, mytho-poetically in the works of Cormac McCarthy and in the popular culture of rap and rock music.

10 It may be possible to develop a superior iteration, though I have yet to see any candidates.

11 Sometimes this is referred to in the literature as a speaker's community, or a lifeworld in the continental tradition. I have decided to use the phrase "community of language users" to elide the controversies between phonetic and textual interpretation. For my purposes "community of language users" denotes a collection of language users who share and deploy relatively the same grammar in a manner that is semantically meaningful to other language users.

12 Indeed, many have pointed out that specialized legal terminology proves to be a problem for many individuals who are confronted with legal processes and are intimidated by its divergences from ordinary language. This sense of alienation transforms their legal consciousness. 
There is no plain meaning to the word "gun" that can be found in a given linguistic community at whatever period in its history. At most, things like a dictionary might give us some hint as to the way this word is used in the various "games" that people play with their language. [8] It would certainly not denote the intrinsic meaning of the word in all contexts.

All this suggests that if we wish to take context seriously, as a textualist like Scalia does, then we have to acknowledge that the range of semantic associations linked to a given term, and thus the range of legitimate meanings potentially associated with it, is immense and constantly growing. The range of possible meanings at any time depends on (1) the immensity of the semantic associations ready at hand in a community of language users, and (2) the creativity of individual members in generating novel associations through adapting and developing new ${ }^{13}$ games [9] (p. 231). Those who hold to the plain meaning view in law, such as textualists, must be indifferent to (2) since that concerns the way the meaning of terms changes over time. They can acknowledge that meaning does change through novelty but insist that legal officials just look to the original plain meaning. They are entitled to that. But this does not get those who hold to the plain meaning view off the hook. This is because of the consequences of (1).

At its most radical, but also its most consistent, (1) suggests that meaning is entirely or largely holistic. This was implied in Wittgenstein's work, and later became a seminal thesis in the philosophy of Quine, who suggested that the epistemological tenability of propositions could only be assessed relative to its associations in the whole of a given body of knowledge. ${ }^{14}$ This position, it is worth noting, was fundamentally anti-positivist. There was no way, on Quine's account, to settle to the meaning of words once and for all since such semantic questions depended on the status of the whole body of associations [15]. This position, and the position of holists generally, was nicely summarized by Hilary Putnam.

Holism is thus, in the first instance, opposed to positivism. ${ }^{15}$ The positivist view of language insists that all meaningful descriptive words in our language must have definitions in terms of words in a 'basic' vocabulary; a vocabulary which consists of words which stand for notions which are epistemologically more primitive than, say, the theoretical terms of science. If we formulate positivism as a thesis about the truth conditions for sentences rather than as a thesis about the definability of terms, we may say that, as a historical fact, positivists originally insisted that the meaning of a sentence should be given by (or be capable of being given by) a rule which determines in exactly which experiential situations the sentence is assertable. [7] (p. 21)

If meaning holism is correct, as many think it is, the consequences would be devastating for plain meaning theories, such as textualism. This is because it seems that taking context seriously would entail dropping the plain meaning view. Meaning holism heavily implies that truly unpacking the semantics involved in a statement would involve dropping what one might call the positivistic assumption (I would say preference) that terms must have a "limited range" of plain meanings [12] (pp. 24-25). Indeed, the very idea that any individual term has a meaning becomes untenable.

The implications of this for textualist legal analysis, and other iterations of the plain meaning view, are quite striking. If meaning holism is valid, it would seem to suggest that we must interpret all legal writing as a whole: all the associated legal rules, precedents, and conventions have some

13 For exegetical purposes I will engage this more closely in the conclusion.

14 The terminology deployed by Quine is not mine, but I have replaced it to be consistent with the remainder of the section.

15 The relationship between philosophical positivism and legal positivism is complex. I do not think the holism challenge would necessarily destabilize the positivism of Hart or Shapiro for example. They never claimed that legal terms apply unambiguously. Their positivism is more concerned with separating law and morality. Though the tenability of this might still be shaken by the holism challenge, it does not need to be devastating. Indeed, Hart took these concerns seriously in his account of the "penumbra." The holism challenge does seem to pose devastating problems for the positivists, such as Scalia, who want to insist that legal terms can be applied unambiguously. 
interpretive gravity when attempting to determine how a given law is to be understood and applied. ${ }^{16}$ Since it is impossible to be so omniscient, it suggests that all legal interpretation is at least to some degree partial. A judge does not discern the plain meaning—past or present—of a term. They only take their best shot at it.

I will leave these thoughts here for now because I believe they demonstrate certain basic problems with the plain meaning view and its textualist iteration. That is, if they take context seriously enough, as they must, then advocates of the plain meaning view are pushed towards a type of holism wherein the central thesis of their theory-that terms have an unambiguous meaning- becomes untenable. This suggests that, whatever the preference of legal advocates of the plain meaning theory, it may simply be impossible to have a language which can be interpreted in the way they need it to if one is to give a purely originalist interpretation.

Some might think that the kind of meaning holism implied here suggests an anything-goes mentality, indeed, that we are approaching a kind of skeptical anarchism about the very possibility of any term having a set meaning. And as we shall see, some theorists drew exactly that conclusion. Later, I will try to suggest that this extreme solution is mistaken as well.

\section{The Indeterminate Theory}

The second theory of linguistic meaning I will be looking at is the indeterminate theory. The indeterminate theory holds that there is no set or foundational meaning to any semantic term in the law which stipulates how it can be objectively applied by legal practitioners. This means that, since no legal officials render an objective decision, we must look externally to understand what determines the outcome of legal cases. As nicely summarized by Mark Tushnet

... drawing on-or perhaps simply reviving for a new generation-insights from American legal realism, critical legal scholars argued, in one doctrinal area after another, that the purely legal materials at hand (statutes, precedents, "policies," whatever) underdetermined results in actual cases. As critical legal studies developed, bold and overstated claims that all results were underdetermined were replaced by more defensible ones, to the effect that many results were underdetermined, or that results in many interesting cases were, or-as in Kennedy's version - that enough results were underdetermined to matter. ${ }^{35}$ One or another of these revised versions of the indeterminacy argument is, I think, accepted by nearly every serious legal scholar in the United States. [16] (p. 108)

For many who hold to the indeterminate theory, the argument is that one must look at the knowledge/power structures which contextualize a case if one is to understand how a legal official reaches a decision. Much like the plain meaning view has iterations like intentionalism and textualism, the indeterminate view is often associated with various critical theories that want us to see that the belief that legal terms have a clear meaning is an illusion used to mask various forms of hegemonic domination under the guise of formalism.

Of course, my summary cannot capture all the many and varied forms of the indeterminate theory which have emerged over the years. The indeterminate theory has been put in many different ways, some more focused on language than others. An iteration of the indeterminate theory might be traced back to the legal realist movement, especially its more radical members like Jerome Frank [17]. ${ }^{17}$ However, for the purposes of this essay, I will be focusing on the more radical—both theoretically and politically-iterations to have emerged since the 1970s. With that in mind, one must reference

16 This would bring one very close to Dworkin's pioneering analysis going back as far as Ronald Dworkin; "Hard Cases." However, Dworkin would not follow the same steps here because he regards moral and descriptive-semantic forms of interpretation as being philosophically distinct. What the difference is remains somewhat mysterious to me, since Dworkin's account of why moral and descriptive-semantic forms of interpretation are distinct strikes me as unconvincing.

17 The position of someone like Holmes' seems more moderate. 
Duncan Kennedy's early conceptual analysis of the interplay between form and substance in the law, with the conclusion that one cannot infer the latter from the language of the former despite the formalistic pretensions of many legal officials [18] ${ }^{18}$ There is Roberto Unger's ${ }^{19}$ critique of the "objectivist" theses of "formalism." [19] More recently, as critical legal studies gave way to a variety of critical approaches to law and to the law and society movements, one saw the influence of Foucault and discourse theory flourish. One can look at the work of Mariana Valverde who dismisses law's "dream of a common knowledge," 20 Susan Silbey's discursive approach to the production of legality and the legal consciousness of law's subjects, and Allan Hutchinson's claim that the meaning of the common law is inevitably evolving, often according to the directives of power legal officials $[3,20,21]$.

So far, I have said very little about how linguistic meaning relates to the indeterminate view. And indeed, not all of these indeterminate theories are specifically centered around linguistic meaning. But most, if not all, seem to presuppose it to some degree. This is because if it were possible to develop a theory of linguistic meaning which was determinate in any strong sense, it would undermine the belief that law was necessarily indeterminate. Were it possible to say that most or all legal terms have a determinate meaning both semantically and in their application to empirical circumstances, then the motivation to look externally at knowledge/power structures would change substantially. If law was determinate, the only motivation to look externally would be to criticize either the "substance" and "effect" of a given set of legal terms in their application to the world or to criticize the legal system as a whole from a more total perspective. Put another way, one could not say that legal officials made a political decision if it was clear that they arrived at the right answer according to some formalistic theory, like the one often attached to the plain meaning view. One could say only that a particular law was wrong, or that the legal system as a whole was unjust-perhaps pushing one towards a critical natural law perspective or perhaps more radically to some variant of a classical Marxist theory about the law existing as superstructure which is in some senses determinate but operates to serve only to serve the interests of certain powerful social groups [22].

Many who now hold to the indeterminate view might accept some of the premises of these critical approaches. However, what makes the views of those who hold the indeterminate view unique is their claim that legal officials do not just occasionally apply bad laws according to the duties of their office, or that they do so in a bad legal system. The claim is that legal officials are fundamentally mistaken about what they are doing since the belief that they are simply applying the law according to its plain meaning is fundamentally mistaken because there simply is no plain meaning to legal terms. This is because there is no sense in which legal terms unambiguously hook on to objects in the world in some positivistic manner. Radicalizing Wittgensteinian ideas, ${ }^{21}$ advocates of the indeterminate theory claim that in essence judges and other legal officials play a language game that is determined by contingent knowledge/power structures that both exist outside the law and determine the application and understanding of legal terms within the discourse of legality. This also has moral consequences. Since there is no unambiguous way to apply legal terms, what actually determines their applications

18 In his later work Kennedy seems to have adopted a more overtly Foucaultian slant, which amongst other things is why I deploy Foucault in a manner similar to Scalia in the last section. He is a representative foil for all the iterations of the indeterminate view.

19 One must be very careful here since Unger never embraced the more skeptical moral conclusions adopted by other critical legal scholars.

20 Recently she seems to have moved in a more constructive dimension, cautiously engaging with Bakhtin and (god forbid) even Kant.

21 When his ideas are deployed by those who hold the indeterminate view, Wittgenstein is often treated as a radical skeptic. And while one can certainly choose to push his thinking in that direction, I do not think that is fair to the general orientation of his thinking. Wittgenstein's critique of rule following does undermine certain dogmatic interpretations of the plain meaning view, for instance, that the application of every term follows from some clear rule dictating how it is to be applied in every empirical context. However, he softened the extreme consequences of his thesis by appealing to the social determinants of semantics, for instance, in his appeal to forms of life and language games. This pushes him closer to what I will later call the soft pragmatism argued for in the conclusion. There are certainly few senses in which he seemed to hold to the indeterminate view as connoted here. 
is not the semantic rules of a given linguistic community, but knowledge/power structures that often serve to reinforce given social interests and marginalize others. ${ }^{22}$ As put nicely by Allan Hutchinson:

While no less passionate and no more accepting in watching and playing both games, I have developed a more refined and nuanced stance that is intended to remain as uncompromising in its ambitions as it becomes more compelling in its actualisation. In both instances, I believe that the games of law and soccer are thoroughly political and that, like war, they are the continuation of politics by other means. I defend this, not only as one way of looking at each activity, but as something integral to their playing and performance. It is not that law and soccer are like politics, capable of being metaphorically understood in terms of each other, but that law and soccer are arenas and activities of and for politics. This is not to essentialize law, soccer and politics or claim that, deep down and in their basics, there is Really Something that law, soccer and politics are about. On the contrary, I insist that what is presently claimed to be the most favoured way to play the game is simply a melange of historical accident, human design, political sensitivities and economic interest. My earlier mistake, as soccer player and legal theorist, was thinking that there was a Best Way to do law or play soccer and that I knew what that Best Way was. [23] (p. 265)

\section{Law's Politics and Discourse Theory}

As mentioned, this account of the relationship between legal terms, knowledge/power, politics, and linguistic meaning is cast in many different ways by those who hold to the indeterminate view. However, many of them, particularly in socio-legal studies, adhere to the so-called discursive account of linguistic meaning. The discursive approach pioneered most famously by the early Foucault in the Order of Things, and more prominently in his Archaeology of Knowledge, stresses the social contexts which lead to the establishment of a language in which various systems of knowledge congeal [24,25]. L1ike the pragmatism, Foucault's discursive approach to language radically eschewed the positivism which colored early 20th century philosophies of language. He stressed that language did not simply represent, or "picture" in the early Wittgenstein's vocabulary, the "real" world of facts or things [4]. ${ }^{23}$ Language played an active role in establishing what subjects would take as the objective parameters of the world. These parameters were often established before we were born, they were the "archive" of meanings within which we came to exist. The "archives" of meaning through which we understood our lives were very often established by systems of knowledge/power which used knowledge to crystallize the realm of possibilities opened to human beings within various epochs. The unconscious archive establishes into which "enunciative field" a given statement, say a statement of fact, will fall, by defining how its apparent content is to be objectified and ordered [25] (pp. 330-370).

"The statement is not a direct projection onto the plane of language of a particular situation or a group of representations. It is not simply the manipulation by a speaking subject of a number of elements and linguistic rules. At the very outset, from the very root, the statement is divided up into an enunciative field in which it has a place and a status, which arranges for it its possible relations with the past and which opens up for it a possible future." [24] (p. 111)

Occasionally, a connection will be drawn between enunciative fields. This will most often take place when the themes, methods, inner logics or some other quality is consistent between the fields. In these cases, the enunciative fields will combine to form a discourse, for instance, the discourse around the nature of legality, which allows individuals to interpret data and further statements in a manner consistent with the inner discursive logic around the subject matter. Successful discourses

22 As I will indicate later, I do not think this approach to Wittgensteinian language games is accurate. Those who hold to the indeterminate view regard the rules of the game as at once set by power, and entirely contingent. One of the points is to remove or ignore the rules determined by power and reveal the contingency of legal terms. This would not be the position of Wittgenstein, as I will explore later.

23 The so-called picture theory of language was developed by Wittgenstein very early on. 
are those which are able to maintain their social standing in the face of contradictions. They are not successful because they in any way adequately hook onto the real world or speak some truth to power. They succeed because they reinforce power [26].

I take Foucault's analyses to be the exemplar of the indeterminate theory of linguistic meaning. His work also nicely demonstrates the connection drawn between legal terms, knowledge/power, and politics. The discourse of legality, on the surface of it, appears to be about how to apply the unambiguous plain meaning of legal terms to the given social situations they refer to. However, once one abandons the plain meaning view for one which is more indeterminate, we see that in fact legal terms are interpreted and applied by judges and other legal officials in a manner that is designed to discipline subjects in accordance with the inner logic of a given order of knowledge/power. Often this order is designed by and supported through powerful institutions and groups in society, and it is their interests that get reflected in the makeup on law and in its application. This is why judges are compelled to interpret the law to preclude the development of a robust set of economic rights for individuals, even though the language of the Bill of Rights might enable them to do so if the terms were linked with a more emancipatory discourse [2,22]. It is why certain cultural perceptions of property rights and history are privileged over others in the development of both the Constitution and constitutional jurisprudence.

I believe that there is a great deal to be said about the virtues of the indeterminate view and its affiliated politics. However, I feel that, as with advocates of the plain meaning view, those who adhere to the indeterminate theory are often more committed to a theory of linguistic meaning for moral reasons rather than because they actually feel that is a good account of the subject. Those who advocate for the indeterminate theory want to demonstrate that the semantic norms governing linguistic use are dominated by a "micro-physics" of knowledge/power which marginalizes important voices. In many respects, this may well be true [26] (pp. 298-306). But that cannot account for many of the apolitical and indeed, useful features of language and linguistic meaning. In my opinion, those who hold to the indeterminate theory have neglected three key issues.

The first issue is empirical. The indeterminate theory of linguistic meaning cannot give an account of the "communicative" functions of language emphasized by pragmatists such as Rorty, Price, and especially Habermas [27-29]. The communicative function highlights that individuals engage in linguistic dialogue with one another intending some effect or affect to take place which is dependent on the interlocutor interpreting the speech act or written text in a more or less determinable manner. Because most speech acts and written text seem to function this way, individuals in a given linguistic community can coordinate their social lives according to more or less regular and "useful" patterns. Pragmatically, it seems to me that this position has a lot going for it. While miscommunication and isolation may be prominent in the deepest and most complex dimensions of our lives, say in rich interpersonal relationships, the more mundane communication we engage in relying on many "rigid designators" ${ }^{24}$ like proper names does not have a sufficient thickness of semantic associations to become ambiguous.

The second issue are the totalizing features of certain iterations of the indeterminate view. To give one prominent example, Foucault's indeterminate theory of meaning is based on an account of discourses is totalizing. He cannot conceive how any discourse could evolve rather than simply adapt itself to the presence of thematic or empirical contradictions. However, discourses are not set in stone. According to Foucault's own account, they react and change and can even be discarded. Why this happens, he cannot say beyond pointing out how it occurred historically and looking to the knowledge/power promoted by groups that wield control at any given time. But if it were true that knowledge/power groups wielded such total control, then one could not explain on what basis they could be overcome. If there were no external conditions for assessing the validity of statements, why

24 I will explain the use of this term shortly. 
would a discourse change if it were sufficiently powerful to determine the application of terms and faced no considerable challengers?

However, that discourses changed would be no surprise to pragmatists, who claim that the communicative functions of language are predicated on soft, but universal, conditions for establishing the validity of statements, such as truth condition about statements of empirical fact. This accounts for why, when confronted with contradictions, discourses may evolve or be discarded depending on how well they can assimilate new data established by appeal to truth conditions. If they cannot, discourses may well be discarded as incoherent or no longer valuable. This is why Robert Brandom, in a Hegelian vein, refers to the role of logic as an "organ of semantic" self-consciousness [30]. I shall take this up again shortly.

The third issue of the indeterminate theory of language is that indeterminate theories of language fail to give an account of how any language could emerge at all. To give an account of the development of language generally, it is not enough to approach it from a historical perspective since such only illustrates the results of language use rather than providing a deep theory of how and why the language faculty develops in human consciousness. Here Noam Chomsky is informative. Chomsky illuminatingly stresses a critique of the indeterminate theory, and its excessive focus on the empirical and historical, throughout the development of his rationalist approach to linguistics. He argues that claim that a given language develops in a subject purely as a result of the contingent knowledge/power conditions they exist within is akin to arguing that if one placed a baby, a stone, and a tomato in London they would all be equally likely to learn English. ${ }^{25}$ [9] (pp, 163-164_What distinguishes a human being, and its consciousness, from these simpler objects, is that consciousness possesses a unique capacity to generate a language and determine the grammatical rules for its use. Referencing Humboldt, Chomsky claims:

Applying a rationalist view to the special case of language learning, Humboldt (1836) concludes that one cannot really teach language but can only present the conditions under which it will develop spontaneously in the mind in its own way. Thus, the form of language, the schema for its grammar, is to a large extent given, though it will not be available for use without appropriate experience to set the language forming processes into operation. Like Leibniz, he reiterates the Platonistic view that, for the individual, learning is largely a matter of Wiedererzeugung, that is, of drawing out what is innate in the mind. This view contrasts sharply with the empiricist notion (the prevailing modern view) that language is essentially an adventitious construct, taught by 'conditioning' (as would be maintained, for example, by Skinner or Quine). [31] (p. 135)

I believe that all three of these criticisms, about the communicative function of language, its non-total nature, and the rationalistic account of how language develops, are going to be important when arguing for a soft-pragmatism about linguistic meaning and its relevance for the law. In the final section, I will argue that we should adopt such a position when trying to understand what it is that judges and other legal officials do when applying legal terms.

\section{Conclusion: Legal Language and a Soft Pragmatism about Meaning}

The previous sections in this paper criticized two theories of linguistic meaning popular in the philosophy of law. I called the first the plain meaning theory. The plain meaning theory holds that the meaning of legal terms is a settled thing, and it is the duty of legal officials, especially judges, to simply apply that meaning to a given case in hand. The second theory of linguistic meaning examined was called the indeterminate theory. The indeterminate theory holds that there is no set or foundational meaning to any semantic term in the law which can be unambiguously applied by legal practitioners. 
In both cases, I claimed that advocates for their specific theories often seemed more motivated by moral commitments than considerations on the actual nature of linguistic meaning. Those who hold to the plain meaning theory are concerned to preserve the possibility that judges can be truly objective, often through applying the textualist plain meaning of a legal term so as to be consistent with an originalist theory of democracy. For those who held to the indeterminate theory, they were concerned to show that claims about legal objectivity masked the real ambiguities involved in applying legal terms. Yet claims about legal objectivity persist and operate as a kind of knowledge/power discourse because such claims serve the interests of various powerful institutions.

Here I will make another generalization that segues nicely into my discussion on soft pragmatism. I feel that advocates of both the plain meaning view and the indeterminate view are pushed to these respective extremes because of the heavy emphasis legal philosophy puts on so called hard cases. These are those cases which almost every law student will learn about early on, and which often are recalled and debated beyond their time. Sometimes they are even (gasp) well written, and leave an aesthetic impression. ${ }^{26}$ They almost always involve a dramatic, even defining social issue, there is usually persistent philosophical debate about whether the judges reached the right decision, and legal philosophers will almost always use these cases as litmus tests for the young. ${ }^{27}$ They are so pedagogically useful in part because there is always so much to agree and disagree with in these hard cases, Roe vs. Wade being the canonical example to this day. However, this is part of the problem. The excessive emphasis on hard cases can lead us to assume that a great deal of law can be similarly controversial. In part this is what leads, I believe, to both the pieties of the plain meaning theory and the radical skepticism of the indeterminate theory. Those who hold to the plain meaning theory are convinced that, since there can only be one set of laws for all time, there must be a right answer to all disagreements. Those who hold to the indeterminate theory hold that, since deep disagreement is possible in hard cases, and cannot be resolved unambiguously, therefore there is no such thing as a right answer in any case.

Both approaches, I believe, are mistaken. Following Brian Leiter, I feel that we must be considerably more cautious in our evaluations of the law and stop engaging in top-down reasoning which grants such pride of place to hard cases [32]. As Leiter puts it, it seems to me that in the vast majority of cases, legal decisions flow fairly unambiguously from the text of law. Or at the very least, the answer is clear enough so as to permit relatively little disagreement that cannot be dealt with through appeals and a closer look at the facts of the case. Whether this is a good thing or a bad thing depends on the morality of a given law, and indeed of the legal system as a whole. But this does not mean that there are not cases where the legal terms cannot be applied without deep ambiguity.

This is where my argument for a soft pragmatism comes in. As my primary intention in this paper was to criticize the plain meaning and indeterminate theories of language for their extremism, the characterization given in this conclusion will be fairly general and exploratory. In future work, I hope to sketch out this position in considerably more detail. My soft pragmatism follows Leiter in arguing that law, in many cases, operates with fairly little ambiguity. In these cases, there is indeed a right answer to a legal case [32]. This includes a considerable number of reverse onus cases, where there are comparatively "rigid" answers to the empirical questions at the heart of a legal dispute. But there are many other cases—what Hart might call penumbral cases [33] (p. 607)—where the legal dispute cannot be settled by finding a "rigid" answer to an empirical question. In such cases, there will inevitably be semantic ambiguity, we cannot say that there is some right answer to a legal question. Instead, legal officials must engage in semantic reflection about the meaning they wish to ascribe to a given set of legal terms. This supports the legal realist position that in such cases, whether this is a good thing or a bad thing, judges will resolve a legal question by making political and moral choices

26 Holmes' dissent in Lochner is a classic example. See Lochner vs. New York, 198 US 45 (1905).

27 Though as Waldron put it, the very distinction between easy and hard cases, while useful, is hardly easy. 
based on their preferred outlook. One of the reasons why I believe the indeterminancy theory has gained such traction amongst legal theorists, outside of its appeal to a certain kind of left-wing outlook, is that many of the "hard" cases which do not beget of easy answer are those which pertain to the most interesting and probing issues of our day. The question of whether abortion can be related to privacy may not beget an unambiguous legal answer, but it certainly has an importance one would not immediately grant to violations of traffic and speeding laws.

First, we will start by discussing the non-ambiguous cases. I think that in many situations there may well be a right answer to most legal cases, in the technical sense that a judge or legal officials must apply a given legal term to a situation and render a judgment on the extent of their conformity. I think there is likely a right answer because many of the legal terms found in law designate quite rigidly. One of the ways to avoid hyper-skeptical consequences, such as the views propounded by the indeterminate theory, would be to drop the global pretensions of the positivistic thesis about semantic meaning. Instead, we could say that some words have a more rigid association with certain objects or concepts than others ${ }^{28}$ to the point where some statements might be analytically true a priori or necessarily true a posteriori rather than just through their web of associations. This might look something like adopting a Kripkean scheme of distinguishing between rigid and non-rigid designators. These would be statements of truths about a unique object which apply in all modally possible worlds [34].

The importance of this for legal theory is that some "rigid" legal statements might apply with less ambiguity than others. To put it in Kripkean terminology, some legal statements might be interpreted the same way in all possible court rooms [6]. This is especially true of circumstances where there is an unambiguous empirical answer which can be given in a legal dispute. In these circumstances, any ambiguities would relate to fact-finding efforts and dishonesty, rather than the semantics of law itself. I will provide just a few examples to ground my meaning. With regard to the American Constitution, it seems clear that provisions such as Article I, Sec 2 that "no person shall be a representative who shall not have attained to the age of 25 years, and been seven years a citizen of the United States, and who shall not, when elected, be an inhabitant of the state in which he shall be chosen" or the 20th Amendment that the "terms of the President and Vice President shall end at noon on the 20th day of January, and the terms of senators and representatives at noon on the 3rd day of January," could fall into this category. While the terms may not designate as rigidly as in certain other statements, their meaning seems fairly unambiguous when applied to objects and concepts in the world. The same lack of ambiguity pertains to laws which deal with highly technical and specific subject matters. I also think that most of the legal terms in reverse onus cases likely designate quite rigidly. As Leiter would point out, this may well include most forms of reverse onus regulation, though making such a determination would involve extensive socio-legal research and theoretical analysis [32]. Conjecturing somewhat broadly, it seems to me that in cases where one is not allowed to park between the hours of 8 p.m.-6 a.m., or to drive above the speed limit, the legal terms apply quite rigidly to their subject matter. One either parked in that zone during the prohibited time or one did not. The same likely applies to many laws on the sale of liquor and controlled substances and a fair number of tax laws. As nicely put by Jeremy Waldron:

Think of the least vague expression you can imagine being used in legislation-say, "less than twenty-one years old" in an ordinance prohibiting serving alcohol to minors. The phrase itself does not light up in the presence of an infant and then go out in the presence of a forty year old, like an ultra-sensitive neon sign at the doorway to a bar. The rule about not serving people under twenty-one is not like a Geiger counter that emits a loud clicking whenever a teenager enters the premises. Even when expressions are precise, it is people who must apply the words. [35] (p. 510)

28 This was once referred to as the "cluster" formulation. 
The account discussed above might seem to provide a great deal of support to the plain meaning view, which problematizes my characterization of this position as a kind of "soft pragmatism." But that is not the case. Rather like Kripke's theory of rigid designators, albeit more loosely than is permitted in the realm of modal logic, my account is concerned only with legal terms that unambiguously apply in all possible worlds at all possible times. I by no means think it is possible to determine the "original meaning" of a word, nor do I think that many legal terms have a plain meaning even in the present. More specifically, I do not think that many constitutional cases, of the type so dear to originalists who never miss a chance to idolize their sacred document, involve many such rigid designators. The originalist project, like all plain meaning accounts, only really gets a lot of truck in fairly mundane cases like those where reverse onus principles are applied. This does not pertain to many of the major cases which reach the Supreme Court and deal with the great issues of the day. This is because I do not think that there is any sense in which significant portions of the constitutional text can be said to designate in any rigid way. At most, much of it seems akin to bullet points or abstract principles ${ }^{29}$ which can only take on meaning as a common-law collection of semantic associations develops over a period of time. To give just a few examples, there seems little sense in which the 14th Amendment's commitment to providing "equal protection of the Law" or Article IV, Sec 4 guaranteeing each state a "republican form of government" can be construed as in any way rigid. Indeed, the former has been subject to quite radically different interpretations which lean heavily on the normative rather than semantic way in which judges and theorists interpret equality. ${ }^{30}$ And the latter has been the subject of centuries of debate about what precisely is meant by a "republican form of government."

Some may ask why I characterize this position as a kind of "soft pragmatism" rather than simply comprehensive pragmatism à la the legal realism of Justice Holmes, Jerome Frank, and others [17,36]. ${ }^{31}$ The reason is that I think such figures go too far in their support of the indeterminancy theory, often flirting with the kind of radical anti-foundationalism which found its most nuanced philosophical defense in the work of Richard Rorty [37]. However, my position is considerably less extreme than this. In cases where we are dealing with rigid legal statements concerning empirical issues which can be settled by an appeal to facts, there is no need for pragmatic deliberation concerning the resolution to the problem. As mentioned, this may well include a significant proportion of legal cases, though socio-legal research would need to be undertaken to establish that. However, I think once we move beyond such cases, and are dealing with the kinds of ambiguity discussed above, judges have no choice but to engage in pragmatic deliberation to determine an answer to a legal case. The cases where this may be necessary will often be the most dramatic, contentious, and important ones dealt with by legal officials. To clarify this, I will discuss this deliberative process of semantic self-reflection in some detail below.

\subsection{Pragmatic Deliberation When Dealing Semantic Ambiguity in Richardson v. Ramirez}

What form then does this pragmatic deliberation take? I will only sketch out the answer here and provide a short example below. In circumstances where judges are dealing with a legal problem involving semantic ambiguity, they can engage in a logical exercise to try and determine its meaning. But this "logic" is not the kind of strict procedure one can see in the modal situations interpreted by Kripke. Instead, it is a concern for a kind or normative consistency which provides a sufficient,

29 The ontological status of abstract principles is itself a complex philosophical question. It seems quite clear they cannot be rigid designators. Principles seem somewhat akin to quasi-Platonic entities which are the creation of the human mind but none the less are independently reason giving.).

30 One of the most radical is Ronald Dworkin's, who interprets the 14th Amendment to require the state to undertake massive redistributive programs.

31 This can have realist or pragmatic interpretations. A legal realist would accept this and go even further in saying that all law happens to be what judges want, for good or ill. A legal pragmatist would suggest that judges should look to evidence available to them and fit the law to bring about the best solution. I have sympathy with both of these traditions, but would not accept either wholesale, though my sympathies are with the latter. 
though by no means unchallengeable, interpretation of legal meaning. Following Robert Brandom, we might say that in such cases judges understand and deploy a kind of logic of "semantic self-reflection" about the meaning to be ascribed to legal terms that are inherently ambiguous [30]. When engaging in such semantic self-reflection, judges cannot simply look at the rigid meaning of the word, or even the holistic cluster of associations affiliated with it. Even if meaning holism is correct, they must still make decisions about the relative gravity of certain associations compared to others. This means that legal officials are in no sense being objective. There is always some partiality in judgments, depending on the associations used to construct the semantic meaning of a legal statement. Put more bluntly, it heavily implies that a judge's subjectivity and even preferences will come to bear when deciding a hard case where there are not rigidly designating legal terms. If this is the case, then there is little sense in which originalist judges are being more faithful to the rule of law as it is objectively embodied than other judges. They are simply giving their own partial interpretation, drawing on an eclectic range of associations which may or may not be more valid than any other judges' ${ }^{32}$ Often times, these associations will reflect a judges' preferred political or moral theory. Invoking these political and moral preferences is pragmatically necessary to provide a degree of normative consistency in a case which cannot be resolved through rigid interpretation of semantic meaning. This may be unpalatable for legal theorists and practitioners who support the plain meaning view and may find the claim that there is any application of subjective preferences in "hard cases" to be morally unacceptable. But I think the position presented here is simply a more realistic and accurate appraisal of what happens, given the inherent semantic ambiguity of many of the terms involved in legal disputes.

To provide a short example, consider the reasoning deployed in Richardson v. Ramirez. Richardson was initiated by several plaintiffs who had committed felonies in California but had completed their sentences. They brought a class action suit against the Secretary of State and election officials, arguing that constitutional provisions and statutes which permanently disenfranchised them were unjustifiable. The plaintiffs argued that California did not have a "compelling state interest" in permanently disenfranchising them, which had been the precedent established earlier in Dunn $v$. Blumstein. Unfortunately, while they won at the state level, the Supreme Court backed away from narrowly interpreting "compelling state interest" and demanding California enfranchise convicts. The justices drew on plain meaning theory to develop a formalistic interpretation of the Fourteenth Amendment, which stressed that Sec 2 indicated that voters can be disenfranchised for participation in "rebellion, or other crimes." Here, the orientation of the Court comes across as deeply originalist, and highly proto-textualist, as they stressed that the legislative history suggests Congress intended Sec 2 to "mean what it says."

The problem of interpreting the "intention" of a constitutional provision is, as countless cases of this Court recognize, a difficult one. Not only are there deliberations of congressional committees and floor debates in the House and Senate, but an amendment must thereafter be ratified by the necessary number of States. The legislative history bearing on the meaning of the relevant language of $\S 2$ is scant indeed; the framers of the Amendment were primarily concerned with the effect of reduced representation upon the States, rather than with the two forms of disenfranchisement which were exempted from that consequence by the language with which we are concerned here. Nonetheless, what legislative history there is indicates that this language was intended by Congress to mean what it says. [38]

They then go on to elaborate upon this conservative interpretation, by stressing that, while Sec 2 might have originally been conceived to disenfranchise those who engaged in crimes against the state, its unambiguous presence and the text of the section tied the justices' hands in this case. Here the justices come very close to anticipating Justice Scalia by arguing that, while there remains controversy

32 They do not distinguish as sharply between intended meaning and the objective historical meaning of words, as Justice Scalia did. 
over whether Sec 2 was intended exclusively to disenfranchise traitors, this history is less important than what the Section plainly "says" and "means" [38].

As we have seen, however, the exclusion of felons from the vote has an affirmative sanction in $\S 2$ of the Fourteenth Amendment, a sanction which was not present in the case of the other restrictions on the franchise which were invalidated in the cases on which respondents rely. We hold that the understanding of those who adopted the Fourteenth Amendment, as reflected in the express language of $\S 2$ and in the historical and judicial interpretation of the Amendment's applicability to state laws disenfranchising felons, is of controlling significance in distinguishing such laws from those other state limitations on the franchise which have been held invalid under the Equal Protection Clause by this Court. We do not think that the Court's refusal to accept Mr. Justice Harlan's position in his dissents in Reynolds vs. Sims, 377 U. S. 533, 377 U. S. 589 (1964), and Carrington vs. Rash, 380 U. S. 89, 380 U. S. 97 (1965), that $§ 2$ is the only part of the Amendment dealing with voting rights, dictates an opposite result. We need not go nearly so far as Mr. Justice Harlan would to reach our conclusion, for we may rest on the demonstrably sound proposition that $\S 1$, in dealing with voting rights as it does, could not have been meant to bar outright a form of disenfranchisement which was expressly exempted from the less drastic sanction of reduced representation which $\S 2$ imposed for other forms of disenfranchisement. Nor can we accept respondents' argument that, because $\S 2$ was made part of the Amendment "largely through the accident of political exigency, rather than through the relation which it bore to the other sections of the Amendment," we must not look to it for guidance in interpreting § 1. It is as much a part of the Amendment as any of the other sections, and how it became a part of the Amendment is less important than what it says and what it means. [38]

Justice Marshall delivered a powerful dissent in this case which took the potential ramifications of prisoner disenfranchisement more seriously and situated it more systematically within the history of American voting laws. Not content to simply look at the (controversial) text of the Fourteenth Amendment, he directly invoked an evolutionary approach to jurisprudence by analyzing the contemporary arguments offered by California to justify its strict laws on disenfranchisement. Justice Marshall found that, beyond its symbolic value, the state could offer little evidence that it had a "compelling" interest in preventing prisoners from voting. Indeed, it only made the extremely spurious claim that allowing former convicts to vote would generate disrespect for law and order because prisoners would be inclined to repeal criminal laws. Justice Marshall dismissed this highly punitive and autocratic reasoning, arguing that parties in a democracy are entitled to disagree with what behavior should be criminalized. Indeed, he pointed out that according to the state's logic, anyone who disagrees with the majority's opinion on criminal law should be disenfranchised. In a stirring paragraph, Justice Marshall opines that voting is the coin of democracy and is fundamentally debased by making the right to vote contingent upon supporting the established order.

Although, in the last century, this Court may have justified the exclusion of voters from the electoral process for fear that they would vote to change laws considered important by a temporal majority, I have little doubt that we would not countenance such a purpose today. The process of democracy is one of change. Our laws are not frozen into immutable form; they are constantly in the process of revision in response to the needs of a changing society. The public interest, as conceived by a majority of the voting public, is constantly undergoing re-examination. This Court's holding in Davis, supra, and Murphy, supra, that a State may disenfranchise a class of voters to "withdraw all political influence from those who are practically hostile" to the existing order, strikes at the very heart of the democratic process. A temporal majority could use such a power to preserve inviolate its view of the social order simply by disenfranchising those with different views. Voters who opposed the repeal of prohibition could have disenfranchised those who advocated repeal "to prevent 
persons from being enabled by their votes to defeat the criminal laws of the country." Davis, supra, at 133 U.S. 348. Today, presumably those who support the legalization of marihuana could be barred from the ballot box for much the same reason. The ballot is the democratic system's coin of the realm. To condition its exercise on support of the established order is to debase that currency beyond recognition. Rather than resurrect Davis and Murphy, I would expressly disavow any continued adherence to the dangerous notions therein expressed. [38]

What we can see here is a classic divide in American law between those judges who employ a process of interpretation of a legal text that stresses its apparent plain meaning and those who wish to substantively assess the arguments for and against a contemporary law. But what becomes clear is that those who argued for the plain meaning theory were at a loss to explain what that meant. When evidence was presented to them that the intention of the lawmakers was to discriminate, they dismissed that as uncompelling. They then proceeded to draw a very narrow conception of equality to suggest that the proper thing to do was respect the text the legislature developed, even if the intent behind it contravened an important constitutional provision. This demonstrates the way that judges will deploy the plain meaning view in order to reach a politically motivated conclusion designed to abet conservative policy. By contrast, the notion of "equal protection" deployed by Justice Marshall was considerably more robust, and I think, no more or less implied by the text of the Amendment.

My point here is not to suggest that one side arrived at the right judicial decision or the wrong one according to some formalistic procedure. It is to demonstrate that there was no one way or another to interpret the case at hand in a manner that demonstrated the proper semantic meaning of equality as it applied in this case. To fill this gap, the judges engaged in the pragmatic deliberation involved in semantic self-reflection. They, in turn, developed a political-theoretical account of what equality should mean in this context and applied it to the circumstances. The point in these circumstances, as I stressed above, was not to develop some rigid theory which could be wholesale applied to the real world, since none was available in these circumstances. Instead, the goal was to develop a consistent logic to justify a given moral position about equality which seemed relatively plausible given the terminology deployed in the text. The judges were, in effect, pragmatic and political in their orientation.

\subsection{Conclusions}

There is much more to be said on this point, but I will end here. My objective in this paper was not to develop a full theoretical account of soft pragmatism as it applies to legal terms. I am simply trying to sketch out a midway point between the positivist pretensions of the plain meaning theory and the hyper-skepticism of the indeterminate theory. It seems to me that both extremes have something to them, but neither is correct in itself. Soft pragmatism splits the difference by saying that in many cases, particularly those in which legal terms rigidly designate, there is a right answer to many legal problems. One might question whether a law or legal system is moral or immoral, but it is clear what the meaning of the legal terms directs a judge or legal official to do. In this respect, soft pragmatism rejects the extreme anti-foundationalism of some legal realists. However, it concedes that there is not such a rigid answer in many of the constitutional controversies that make up the bread and butter material of most legal philosophy. In these cases, very few legal terms rigidly demonstrate, and those that do are often unimportant. Therefore, judges and other legal officials must reflect on the associations they are going to give to a certain legal and will make their decisions by pragmatically trying to develop a logic of normative consistency through semantic self-reflection. This process will often involve their political and moral preferences, as for instance in Richardson $v$. Ramirez where judges were forced to develop an account of equality based on the terminology in the legal text. This deliberative process of semantic self-reflection is, as Dworkin might observe, a constitutional art of sorts which it can take some time to master [39]. But it is certainly not the rigid science that many adherents of the plain meaning view wish it to be.

Funding: This research received no external funding. 
Conflicts of Interest: The author declares no conflict of interest.

\section{References}

1. Goodrich, P. The Role of Linguistics in Legal Analysis. In Legal Discourse: Studies in Linguistics, Rhetoric, and Legal Analysis; Palgrave MacMillan: Basingstoke, UK, 1987.

2. Kennedy, D. A Critique of Adjudication (fin de Siècle); Harvard University Press: Boston, MA, USA, 1998.

3. Valverde, M. Law's Dream of a Common Knowledge; Princeton University Press: Princeton, NJ, USA, 2003.

4. Wittgenstein, L. Tractatus-Logico-Philosophicus; Translated by Pear, D.F., McGuinness, B.F.; Routledge: London, UK; New York, NY, USA, 2002.

5. Dworkin, R. Hard Cases. Harv. Law Rev. 1974, 88, 1057. [CrossRef]

6. Kripke, S. Naming and Necessity; Blackwell Publishing: Malden, MA, USA, 1981.

7. Putnam, H. Representation and Reality; The MIT Press: Cambridge, MA, USA, 1988.

8. Wittgenstein, L. Philosophical Investigations: Revised Fourth Edition; Translated by Anscombe, G.E.M.; Wiley-Blackwell: Oxford, UK, 2009.

9. Chomsky, N. Language and Problems of Knowledge: The Manangua Lectures; MIT Press: Boston, MA, USA, 1988.

10. Perry, M.J. The Constitution, the Courts, And Human Rights; Yale University Press: New Haven, CT, USA, 1982.

11. Bork, R. Neutral Principles and Some First Amendment Problems. Indiana Law J. 1971, 47, 1.

12. Scalia, A. Common Law Courts in the Civil Law System: The Role of United States Federal Courts in Interpreting the Constitution and Laws. In A Matter of Interpretation; Princeton University Press: Princeton, NY, USA, 1997.

13. Strauss, L. Natural Right and History; University of Chicago Press: Chicago, IL, USA, 1953.

14. Wittgenstein, L. On Certainty; Anscombe, G.E.M., von Wright, G.H., Eds.; Harper Torchbooks: New York, NY, USA, 1969.

15. Quine, W.V. Quintessence: Basic Readings from the Philosophy of W.V Quine; The Belknap Press of Harvard University Press: Cambridge, MA, USA, 2004.

16. Tushnet, M. Survey Article: Critical Legal Theory (without Modifiers) in the United States. J. Political Philos. 2005, 13, 99-112. [CrossRef]

17. Frank, J. Law and the Modern Mind; Transaction Publishers: Piscataway, NJ, USA, 2009.

18. Kennedy, D. Form and Substance in Private Law Adjudication. Harv. Law Rev. 1975, 89, 1685. [CrossRef]

19. Unger, R. The Critical Legal Studies Movement: Another Time, A Greater Task; Harvard University Press: Boston, MA, USA, 2015.

20. Silbey, S. After Legal Consciousness. Annu. Rev. Law Soc. Sci. 2005, 1, 323-368. [CrossRef]

21. Hutchinson, A. Evolution and the Common Law; Cambridge University Press: Cambridge, UK, 2005.

22. Mandel, M. The Charter of Rights and the Legalization of Politics in Canada; Thomspson Educational Publishing: Toronto, ON, Canada, 1994.

23. Hutchinson, A. Playing the Game. Dalhous. Law J. 1994, 17.

24. Foucault, M. The Archaeology of Knowledgee; Translated by Smith, A.M.S.; Routledge: London, UK; New York, NY, USA, 2007.

25. Foucault, M. The Order of Things. An Archaeology of the Human Sciences; Routledge Press: London, UK, 2002.

26. Foucault, M. Discipline and Punish: The Birth of the Prison; Translated by Sheridan, A.; Vintage Books: New York, NY, USA, 1975.

27. Rorty, R. Ethics Without Principles. In Philosophy and Social Hope; Penguin Books: London, UK, 1999.

28. Price, H. Naturalism Without Mirrors; Oxford University Press: New York, NY, USA, 2011.

29. Habermas, J. Truth and Justification; Translated by Fultner, B.; MIT Press: Boston, MA, USA, 2005.

30. Brandom, R. Intentionality and Language: A Normative, Pragmatist, Inferentialist Approach. In The Cambridge Handbook of Linguistic Anthropology; Enfield, N.J., Kockelman, P., Sidnell, J., Eds.; Cambridge University Press: Cambridge, UK, 2014.

31. Chomsky, N. Selected Readings on Transformational Theory; Dover Books: London, UK, 2009.

32. Leiter, B. Explaining Theoretical Disagreement. Univ. Chic. Law Rev. 2009, 76, 1215-1250. [CrossRef]

33. Hart, H.L.A. Positivism and the Separation of Law and Morals. Harv. Law Rev. 1957, 71, 593. [CrossRef]

34. Kripke, S. Speaker's Reference and Semantic Reference. In Philosophical Troubles; Oxford University Press: Oxford, UK, 2011. 
35. Waldron, J. Vagueness in Law and Language: Some Philosophical Issues. Calif. Law Rev. 1994, 82, 509. [CrossRef]

36. Holmes, O.W. The Path of the Law. Harv. Law Rev. 1897, 10, 457.

37. Rorty, R. Philosophy and the Mirror of Nature; Princeton University Press: Princeton, NJ, USA, 1979.

38. Richardson v. Ramirez, 418 U.S. 24 (1974). Available online: https:/ / supreme.justia.com/cases/federal/us/ 418/24/ (accessed on 31 March 2019).

39. Dworkin, R. Law's Empire; Belknap Press: Cambridge, MA, USA, 1988. 